\title{
TRPC4AP wt Allele
}

National Cancer Institute

\section{Source}

National Cancer Institute. TRPC4AP wt Allele. NCI Thesaurus. Code C131285.

Human TRPC4AP wild-type allele is located in the vicinity of $20 \mathrm{q} 11.22$ and is approximately $90 \mathrm{~kb}$ in length. This allele, which encodes short transient receptor potential channel 4-associated protein, may be involved in the modulation of both protein ubiquitination and ion transport. 